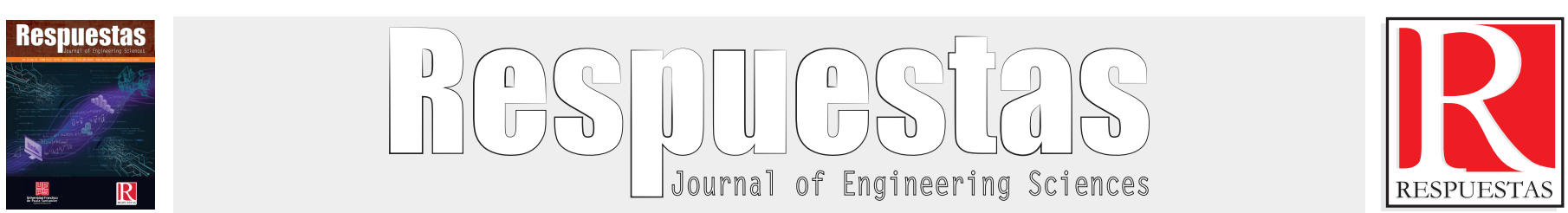

Original Article

https://doi.org/10.22463/0122820X.1614

\title{
Management of intangibles in agricultural organizations as a competitive advantage
}

Gestión de intangibles en las organizaciones agrícolas como una ventaja competitiva

\begin{abstract}
Ender José Barrientos-Monsalve ${ }^{\mathrm{a}^{*}}$, Lloyd Herbert Morris-Molina ${ }^{\mathrm{b}}$, Javier Alfonso Cárdenas-Guitiérrez ${ }^{\mathrm{c}}$, Alvaro Sisa-Vargas ${ }^{\mathrm{d}}$.
${ }^{a *}$ Doctor en ciencias gerenciales, ej_barrientos@fesc.edu.co,orcid.org/0000-0001-6673-0223, Fundación de estudios Superiores Comfanorte, Cúcuta, Colombia.

${ }^{b}$ Doctor en ciencias gerenciales, lloyd.morris@ucp.edu.co, orcid.org/0000-0001-5115-6855, Universidad Catolica de Pereira, Cúcuta, Colombia.

${ }^{c}$ Magister en Administración de Empresas, javierslfonsocg@ufps.edu.co, orcid.org/0000-0002-8097-1223, Universidad Francisco de Paula Santander, Cúcuta, Colombia

${ }^{d}$ Diplomado en Gerencia, alensiva777@gmail.com, orcid.org/0000-0001-7724-651X, Politécnico Grancolombiano, Cúcuta,

How to cite: E.J. Barrientos-Monsalve, J.A. Cárdenas-Gutiérrez, N.A. Rosales-Nuñez and A. Sisa-Vargas, "Management of intangibles in agricultural organizations as a competitive advantage", Respuestas, vol. 23, no. s1, pp. 127 - 130, 2018. https://doi.org/10.22463/0122820X.1614

Received on July 23, 2017; Approved on December 02, 2017

\begin{tabular}{ll}
\hline ABSTRACT \\
\hline Keywords: & The purpose of this work was to make a meditation on the management of intangibles as it is a strategic vision for organizations to be \\
Agriculture & at the forefront of big competitive companies, this research was done under a documentary and descriptive methodology through the \\
Management & analysis of the conceptualizations of knowledge management based on intellectual capital and its dimensions, describing each one with \\
Intangibles & the aspects of agricultural management to determine how to increase the competitiveness of the organization and be able to improve the \\
weaknesses of this type of traditionalist companies, and so they can unblock their state to progress.
\end{tabular}
weaknesses of this type of traditionalist companies, and so they can unblock their state to progress.

\begin{tabular}{ll}
\hline & RESUMEN \\
\hline Palabra Clave: & El propósito de este trabajo fue hacer una meditación sobre la gestión de intangibles ya que es una visión estratégica para que las organi- \\
zaciones estén a la vanguardia de las grandes empresas competitivas, esta investigación se realizó bajo una metodología documental y \\
Agricultura & descriptiva a través del análisis de las conceptualizaciones de la gestión del conocimiento basadas en el capital intelectual y sus \\
Gestión & dimensiones, describiendo cada una de ellas con los aspectos de la gestión agropecuaria para determinar cómo aumentar la competitivi- \\
Intangibles & dad de la organización y poder mejorar las debilidades de este tipo de empresas tradicionalistas, para que puedan desbloquear su estado \\
& y asínar.
\end{tabular}
\end{abstract}

\section{Introduction}

The intangible managements in the organizations are becoming more significant because of their value inside the organizations, [1] Intangible assets are becoming more important developing under the trends of knowledge management, increasing the actives of companies and their importance in the processes of the same. [2] The management of intangibles is directly integrated into the management of resources and capabilities, being assets of the organization that could enter into the dimensions of intellectual capital.

[3] All organizations that are in learning process under an initiative managing knowledge will have a series of goods with material and immaterial parts, which will be an important factor in the strategic planning of the company, starting to know better the markets their capacities and the optimization of their resources to optimize the development of their products. Also this information of the intellectual capital is described by several authors being in different conceptualizations. On the other hand [4] mentioned by Edvinsson and Malone, they propose on the intellectual capital through the example of a tree where there is the visible part and the one that is not appreciated, at least the visible are the leaves, branches, fruits, and the unseen are the roots that must be taken care of in order that they are nutritious and may produce fruits, this metaphor is applicable to the organizations where these only worry about the tangible elements as the assets but not about their intangible qualities, In turn [5] Intellectual capital as a new active of the company, is basically made up of the know-how implicit in the processes of the company and explicitly in the experience of its workers, this experience is essential because through it reengineering is carried out in the processes of organizations, this definition is also focused on the management of knowledge of the company as the previous authors.

As the last definition of intellectual capital [6] quoted from Druker 2001, it establishes as the most important active the human capital where knowledge is the main element of production which belongs to the workers and is untransferable. All these definitions focus on an asset that everyone owns in enterprises and where it should be used to the fullest to improve the competitivity of the business, which is knowledge that is handled through the members of the organization.

These conceptualizations about intellectual capital are structured to conform the levels that compose it, and it is defined by [7] the development of economies where more and more they give less importance to tangible resources, and intangibles begin to take value which are divided into three fundamental dimensions such as: human capital, in reference to the people

*Corresponding author

E-mail address: ej_barrientos@fesc.edu.co (Ender José Barrientos Monsalve)

(c) (i) $(5)($ Peer review is the responsibility of the Universidad Francisco de Paula Santander

cc) (1) (8) $\mathrm{O}$. 
and their knowledge that they have in organizations, structural capital as the

Knowledge that is in the organization and relational capital through the different relationships that the company has with providers, and other organizations creating the necessity to manage knowledge in the organization to ensure competitiveness.

This management, based on the knowledge exists in all the organizations, however these do not give themselves the task of taking them seriously losing this way an added value that can improve their present competitive condition, being that continue establishing under the standards of the traditional administration that do not generate changes in their managements. [8] Radical changes in organizations are the key to attract the customer or user and optimize their advantages. This means that we are now dependent on them and should not be restricted to traditional business practices.

In this way there are many organizations that are going through this situation of loss of value based on intangibles, and the agricultural sector does not escape from this, they are fundamental organizations for the development of any region, however they continue under the traditional models of scientific administration, [9] The agricultural development at the farm level has shown a limited role in the national processes of economic expansion, this is directly related to the prevailing agrarian structure, the poor and unreasonable use of productive resources, the different forms of land possession, and the inexistence of a planning strategy that fulfills the desired objectives.

In this assumption, agricultural management is evidenced by the fact that it follows standards or paradigms of management that have been preserved over time. With this analysis we tried to discern the context of the management of intangibles and the way it is reflected inside the processes of agricultural management.

\section{Materials and methods}

The present investigation was based on a bibliographical investigation, under conditions of documents of secondary sources to link the speech and to think about a phenomenon, being postures of the traditional administration and the intangible managing in the organizations, this by the researches of the compilation of written documents. 10] A specific type of documentary research is the secondary research, this is applicable in documentary research based on reviews, journals, evidence, and other documents that describe situations or realities about the phenomenon under consideration. Likewise [11] The construction of knowledge from sources is a way of watching over the tradition of original thought and, from that perspective, bringing it to the present with a hermeneutic reading that encourages discussion by making new contributions to scientific development. With this, sources were checked describing the scenarios of the management of the intangible and the agricultural managements and to be able to settle down relations between the conceptualizations generating a knowledge based on these aspects.

\section{Results and Discussions}

Agricultural organizations [12] have been defined as places where animals, crops, plantations are managed, being places of sale or distribution of these products for distributors. They may change in some resource requirements, and like the other organizations they are under administrative management standards, these are in a strategic level because they play a role in any economy and administrative management that is oriented to the production.

This type of management continues under the premise of giving importance to production as the fundamental axis of their performance. 13] In view of this, the people responsible for the administration of agricultural organizations must be integrated into the production process, with the design and execution of the different plans to be used in the cropping and stockfarming processes as a fundamental element. The first aspect of the importance of agribusinesses is evident, where tangible assets generated by different internal and external processes.

If we analyze the organizations based on their management and their context on the management of intangibles that could be losing, analyzing the dimensions of intellectual capital to describe the states of agricultural enterprises.

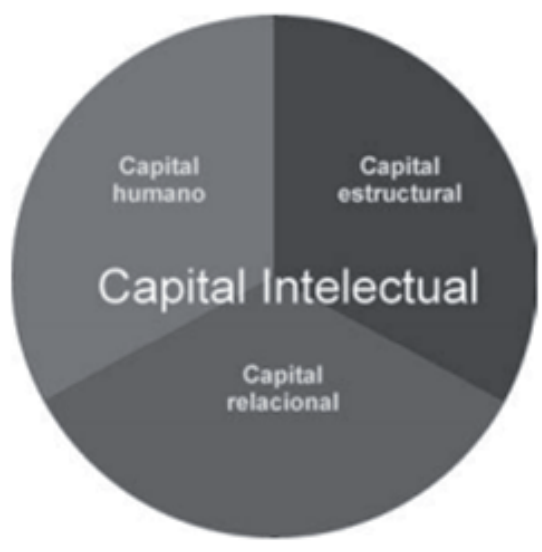

Chart I. Dimensions of Intellectual Capital

Source [14] The intellectual capital among its dimensions, has that the managements are based on three dimensions: the human capital, structural capital and the relational capital. In this way we can associate this type of intangible management to analyze the management in agricultural organizations, by the dimension of human capital. 15] It includes the abilities, attitudes, skills and knowledge that each member of the organization brings to it, meaning, they form individual and non-transfera- 
ble values. This capital can not be owned by the company.

16 In a diagnosis of agricultural enterprises about human capital, it was demonstrated that the development of this dimension is very weak in cases of insufficient personnel training, there are no job definitions, and the management of this capital must be improved.

With this it can be evidenced the loss of intangible value in those structures, where the knowledge that the employees have and which is only theirs because of the management of their responsibilities and daily routines is not being exploited to improve the organization through the attitudes and skills of the employees at the time of resolving and improving the processes of the several situations that come up.

In structural capital [17] among the dimensions of structural capital are the internal processes of the company, such as knowledge or internal secrets, patents, trademarks, routines, infrastructure, and in agricultural enterprises [18] some researchers find that in the scenarios of agricultural administration about the protection and generation of knowledge through the management of patents in this sector are poorly applicable in the agricultural sector, in the same way this type of agricultural organizations.

That's how they're considered. [19] The business tissue of the agricultural sector is composed mainly of Pymes and Micro-pymes, this shows the type of organization that is managed, being small and basic in their management models where only confined to production, and even more when they are companies that have not much formation in their training plans, leaving these inexistent in the process. The intellectual capital reflected in this dimension of the structural capital must fundamentally promote the generation of knowledge inside the implementation of the record of ideas that can help to improve the agricultural processes to take this as a competitive advantage in the organization, also with the formation of knowledge through the work routines improving these experiences to add value optimizing the processes.

Remaining in relational capital. [20] This capital is based on the relations of the company with the costumers, considering their fidelity and the degree of satisfaction, and the agricultural organizations are essential for the communities satisfaction being their principal clients, these companies must consider their satisfaction to improve their product demands and with this to increase prices to improve the company.

In the same way, the relationship they should have with other companies should be used to strengthen their management and strategically to get a better positioning, but the reality of these organizations [21]. Most of the small farmers have suffered losses in the commercialization, due to factors such as: inadequate handling of the product after the harvest, competition with the imported products, lower selling price, change of the demand in the markets and among others. These losses are important for the company's positioning and the structural capital factor plays an essential role because it is not being used as it should be to take advantage of this knowledge, In this type of organizations, the lack of updating in the current paradigms, such as intangibles, is pushing back the processes gradually and obstructing its evolution, leaving it frozen in time without being possible to develop.

\section{Conclusions}

Agricultural organizations have traditional management characteristics, where they have lasted in most companies that follow models based on the scientific management we know, however this model based on processes and productivity, observation and measurement does not give space for some organizations that have not been able to improve their processes and continue in the same situation as long ago, therefore the importance of knowledge management in organizations as a competitive element that has led many companies to increase their positioning.

The importance of the management of intangibles is essential for organization to advance in current competitive scenarios, and agricultural business being typified by their traditional management to move forward must improve these efforts and begin to develop improvement processes based on knowledge management, and with this start to include and give importance to the three dimensions mentioned previously.

These organizations have a huge value through the use of their staff and processes, as knowledge can be improved using the same organization to maximize current assets, and start to value intangibles and use that knowledge strategically in this type of organizations.

\section{References}

[1] K. Ramos, "Conocimiento Activo Intangibles en las empresas," Orionoco Pensamiento y Praxis, ${ }^{\circ}$ Recuperado de: file://C:/Users/DOC\%20INVESTIGACIONES/Downloads/-

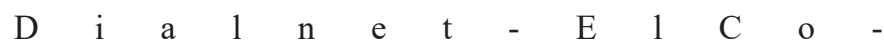
nocimientoActivoIntangibleEstrategicoEnLasEmpr-4003687. pdf.

[2] M. saraur, "La importancia del capital intelectual en las organizaciones," Ciencia Administrativa, no.1, pp. 39-45. Recuperado de: https:/www.uv.mx/iiesca/files/2014/01/05CA201301.pdf

[3] L. Diaz, «Gestión del conocimiento y del capital intelectual,» Revista Escuela de Administración de Negocios, $\mathrm{n}^{\mathrm{o}}$ Recuperado de: $<$ http://sociales.redalyc.org/articulo.oa?i$\mathrm{d}=20611495005>$ ISSN 0120-8160 , 2018.

[4] S. Medina, «El capital intelectual y sus dimensiones,» 
Investigaciones Europeas de dirección y economia de la empresa, vol. V.13, $\mathrm{n}^{\mathrm{o}}$ Recuperado de: file://C:/Users/DOC\%20INVESTIGACIONES/Downloads/Dialnet-ElConceptoDelCapitalIntelectualYSusDimensiones-2356661\%2 $0(3) \cdot \mathrm{pdf}$

[5] S. Henry, «Gestión del conocimiento y capital intelectual,» $\mathrm{n}^{\circ}$ Recuperado de: file://C:/Users/DOC\%20INVESTIGACIO$\mathrm{N}$ E S / D o w n 1 o a d s / 56 - T e x t o \% 20 del\%20art\%C3\%ADculo-271-1-10-20140923\%20(2).html, 2016.

[6] E. Gonzalez, «la medición del capital intelectual y su impacto en el rendimiento financiero en empresas del sector industrial de Mexico,» Contaduria y administración, vol. Vol.62, $\mathrm{n}^{\mathrm{o}}$ Recuperado de: http://www.elsevier.es/es-revis$\mathrm{t}$ a - c o n t a d u r i a - a d m i n i s t r a cion-87-articulo-la-medicion-del-capital-intelectual-S0186104 $216300602,2017$.

[7] D. Escorcia, «La gestión estratégica del capital intelectual en el entorno Latino Americano,» Prospectiva, $n^{\circ}$ Recuperado de: <http://www.redalyc.org/articulo.oa?id=496250978005> ISSN 1692-8261, 2010.

[8] M. Lopez, «LAS ORGANIZACIONES Y LA EVOLUCION ADMINISTRATIVA,» Scientia Et Technica, $n^{\circ}$ recuperado de: http://www.redalyc.org/articulo.oa?id=84911639026

[9] M. Marquez, «LA GESTIÓN ADMINISTRATIVA DE LAS EMPRESAS AGROPECUARIAS DE LOS MUNICIPIOS SAN FERNANDO YBIRUACA DEL ESTADO APURE, EN VENEZUELA,» Revista mexicana de agronegocios, $\mathrm{n}^{\mathrm{o}}$ recuperado de: http://www.redalyc.org/ht$\mathrm{ml} / 141 / 14101002 /, 2002$.

[10] S. Guerrero, «Diseño documental,» Universidad de Jaen, $\mathrm{n}^{\circ}$ Recuperado de: http://www.ujaen.es/investiga/tics_tfg/dise_documental.html, 2015.

[11] L. Gomez, «Un espacio para la investigación documental,» Revista vanguardia Psicologia, $n^{\circ}$ recuperado de: file:///C:/Users/DOC\%20INVESTIGACIONES/Downloads/Dialnet-UnEspacioParaLaInvestigacionDocumental-4815129.pdf

[12] T. S. Corvo, «Empresas agropecuarias: Administración. Tipos, ejemplos.,» Lifeder, $n^{o}$ Recuperado de: https://www.lifeder.com/empresas-agropecuarias/, 2017.

[13] S. Garcia, «las Empresas Agropecuarias y la Administración Financiera,» Revista Mexicana de Agronegocios, vol. vol.40, $\mathrm{n}^{\mathrm{o}}$ recuperado de: http://www.redalyc.org/pdf/141/14152127007.pdf, p. 3, 2017.

[14] S. y. Melián, «El concepto de capital intelectual y sus dimensiones,» Investigaciones Europeas, $\mathrm{n}^{\mathrm{o}}$ recuperao de:
file://C:/Users/DOC\%20INVESTIGACIONES/Downloads/$\mathrm{D} \quad \mathrm{i} \quad \mathrm{a} \quad \mathrm{l} \quad \mathrm{n}$ e $\mathrm{t} \quad$ - $\mathrm{E} \quad 1$ ConceptoDelCapitalIntelectualYSusDimensiones-2356661\%2 0(6).pdf, 2007.

[15] C. Santos, «Capital intelectual. Aspectos para su determinación en la Organización Nacional de Bufetes Colectivos,» Cofin Habana, $\mathrm{n}^{\mathrm{o}}$ Recuperado de: http://scielo.sld.cu/scielo.php?script=sci_arttext\&pid=S2073-60612016000200014, 2016.

[16] J. Villa, «LA GESTIÓN DEL CAPITAL HUMANO EN EMPRESAS DE LA AGRICULTURA. CASO DE UNA GRANJA DE CULTIVOS VARIOS,» Contribuciones a la Economia, no Recuperado de: http://www.eumed.net/ce/2009b/, 2009.

[17] C. Guillermo, «Indicadores de capital intelectual,» Desarrollo Regional, $\mathrm{n}^{\circ}$ Recuperado de: file://C:/Users/DOC\%20INVESTIGACIONES/Downloads/108-219-1-SM.pdf, 2012.

[18] L. Rugeles, «Medición de la innovación agropecuaria en Colombia,» Red Raet de Universidades, $n^{\circ}$ Recuperado de: http://avalon.utadeo.edu.co/servicios/ebooks/innovacion_agropecuaria/files/assets/basic-html/index.html\#4, 2013.

[19] P. Sureda, «Riesgos específicos y su prevención en,» Manual Basico de Seguridad y salud en el trabajo, vol. 3, $\mathrm{n}^{\mathrm{o}}$ Recuperado de: https:/www.aepsal.com/wp-content/uploads/2015/02/MB-agricultura_INVASSAT.pdf, 2014.

[20] C. Blanco, «El Capital Intelectual y las redes del conocimiento,» Innotec Gestión, vol. 4, $\mathrm{n}^{\circ}$ Recuperado de: file:///C: / Us ers / D O C \% 20 IN VES T I G A C I ONES / D ownloads/192-1-699-1-10-20130108.pdf, 2012.

[21] E. Córdova, «Administración de Ventas y Mercadeo Agrícola,»Centra, Ministerio de agricultura y Ganadería, $n^{\circ}$ recuperado de: https://www.jica.go.jp/project/elsalvador/0603028/pdf/production/farm_04.pdf, p. p.01, 2012. 